\title{
The Early Neolithic pottery of Keçiçayiri and its place in the North-western Anatolian Neolithisation process
}

\author{
Deniz Sari ${ }^{1}$, Şemsettin Akyol ${ }^{2}$ \\ 1 Department of Protohistory and Near Eastern Archaeology, Bilecik Şeyh Edebali University, Bilecik, TR \\ deniz.sari@bilecik.edu.tr \\ 2 Department of Archaeology, Çanakkale Onsekiz Mart University, Çanakkale, TR
}

\begin{abstract}
The region of Inner North-western Anatolia was a key node in the transmission of the Neolithic lifestyle from the Near East to Marmara, and from there to the Balkans and the rest of Europe. It formed the intersection between several important routes and trade networks, and the settlement of Keciçaytr, the subject of this paper, had an essential role in the transfer of cultural elements during the Neolithic. The settlement is located on a natural communication route that connects the region of Emirdağ-Bolvadin with Eskişehir across the mountainous area of Phrygia, between the distribution areas of the Hacilar and Fikirtepe cultural groups. Finds from the site include both Pre-Pottery Neolithic material and Early Neolithic ceramics, and it is therefore among the earliest permanent settlements of the Eskisehir region, and contains some of the earliest evidence for the Neolithisation process. In this paper, the pottery assemblage of the Early Neolithic settlement at Keçiçaytr is discussed, and its place in the spread of Neolithisation from the Near East to Northwestern Anatolia is evaluated when compared to other known sites.
\end{abstract}

KEY WORDS - Neolithisation; Early Neolithic pottery; Anatolia; Phrygian highlands; Keçiçayır

\section{Zgodnjeneolitska lončenina z najdišča Keçiçayiri in njen položaj v procesu neolitizacije severozahodne Anatolije}

IZVLEČEK - Območje notranje severozahodne Anatolije je bilo ključno presečišče prenosa neolitskega načina življenja iz Bližnjega Vzhoda na območje Marmarskega morja in naprej na Balkan in $v$ Evropo. Tukaj je bilo pomembno sečišče med številnimi pomembnimi potmi in trgovskimi mrežami, pri čemer je imelo najdišče Keçiçayiri, ki ga obravnavamo v članku, pomembno vlogo pri prenosu kulturnih elementov v času neolitika. Naselbina se nahaja na naravni komunikacijski poti, $k i$ povezuje regiji Emirdag-Bolvadin in Eskisehir preko goratega predela Frigije, in sicer med področjema distribucije kulturnih skupin Hacılar in Fikirtepe. Najdbe vključujejo tako material iz obdobja predkeramičnega neolitika kot keramiko iz zgodnjega neolitika, kar pomeni, da je najdišče Keçiçayiri eno najstarejših stalnih naselbin na območju Eskisehir in vključuje najstarejše dokaze o procesu neolitizacije tega prostora. V članku predstavljamo zgodnjeneolitsko lončenino iz te naselbine in njen položaj pri širitvi neolitizacije iz Bližnjega Vzhoda proti severozahodni Anatoliji, pri čemer ocenjujemo njen položaj v primerjavi z drugimi znanimi najdišči tega časa.

KLJUČNE BESEDE - neolitizacija; zgodnjeneolitska lončenina; Anatolija; Frigijsko višavje; Keçiçayiri 


\section{Introduction}

Following the end of the Last Ice Age, people in the Near East who had subsisted by hunting and foraging began a transition into a lifestyle that included permanent settlement and food production, the first step of a radical alteration that would ultimately be adopted by much of humanity. The earliest Pre-Pottery Neolithic settlements yet identified, and thus the earliest core regions for the transition into farming, are in the Zagros Mountains of modern Iran, the Levant, at Çayönü near the Taurus Mountains and on the Konya Plain in Turkey. Excavations carried out at settlements such as Can Hasan, Așıklı Höyük and Musular indicate that the earliest areas of incipient food production outside the Fertile Crescent seem to have been in the Konya Plain and mountainous area to the east of it. Perhaps the most notable of these is Aşıkl Höyük, near Aksaray, where a few Pre-Pottery Neolithic settlement phases show an overlapping stratigraphy (Özbaşaran, Cutting 2007.55), but the Neolithisation process continued at such sites as Çatalhöyük, near Çumra, which shows many overlapping Early Neolithic layers. Ongoing work in the west of the Konya Plain has greatly clarified the comparative chronologies of the Early and Late Neolithic Periods (Gérard et al. 2002). ${ }^{1}$

Recent excavations in Western Anatolia (Fig. 1) have demonstrated that this area had a role in reshaping the cultures of the Neolithic, rather than simply acting as a bridge for the transition of the Neolithic lifestyle. Mehmet Özdoğan, for example, states that the Neolithic cultures that developed in Western Anatolia and spread to the Balkans and Europe were the predecessors of the European Neolithic, and thus defines Western Anatolia as a Neolithic core region (Özdoğan $M$. 2007.418). Excavations at Bademağacı, in the Lakes District, and at Ulucak, Yeşilova and Çukuriçi, near the Aegean, show that material culture which was clearly influenced by Central Anatolian Neolithic developed differently in the south than in the north. Material from Aktopraklık, Ilıpınar, Barcın Höyük and Yenikapı are representative of the northern Fikirtepe culture and the Neolithisation of the Marmara region.
The settlement of Keçiçayırı, the subject of this paper, is situated on a natural communication route that connects Central Anatolia with Eskişehir, in the mountains of Phrygia, and the southern Marmara coastline beyond. Keçiçayırı was one of the first permanent settlements in this part of the world, and finds show that it was inhabited from the Pre-Pottery Neolithic to the Roman Period.

\section{Brief overview of the Neolithisation of North- western Anatolia}

Despite increasing research, it is clear that there is still much that is unknown about the process of Neolithisation of Western Anatolia, and there are many ways to approach it. Mehmet Özdoğan regards the process of Neolithisation in the Near East, Aegean and Balkans as a series of geographical/cultural zones (Özdoğan M. 2014; 2016). The earliest lie to the east of the Central Anatolian Basin, and are regarded as the regions that saw the formation and development of the Neolithic lifestyle (10 400-7200 BC): Northern Syria and the Levant (Zone A1), Northern Iraq and Western Iran (Zone A2), and South-eastern Anatolia (Zone A3). From the early $7^{\text {th }}$ millennium BC, the Neolithic lifestyle began to spread rapidly, probably due to the effects of geographical, climatic, and social dynamics, and in this period many settlements were abandoned in the east while people moved west. As such, data about the next phases of the Neolithic lifestyle are encountered in the Anatolian Lakes District (Zone B1) and Aegean (Zone B2), in which the number of settlements greatly increased, and in Inner Western Anatolia (Zone C1) and to

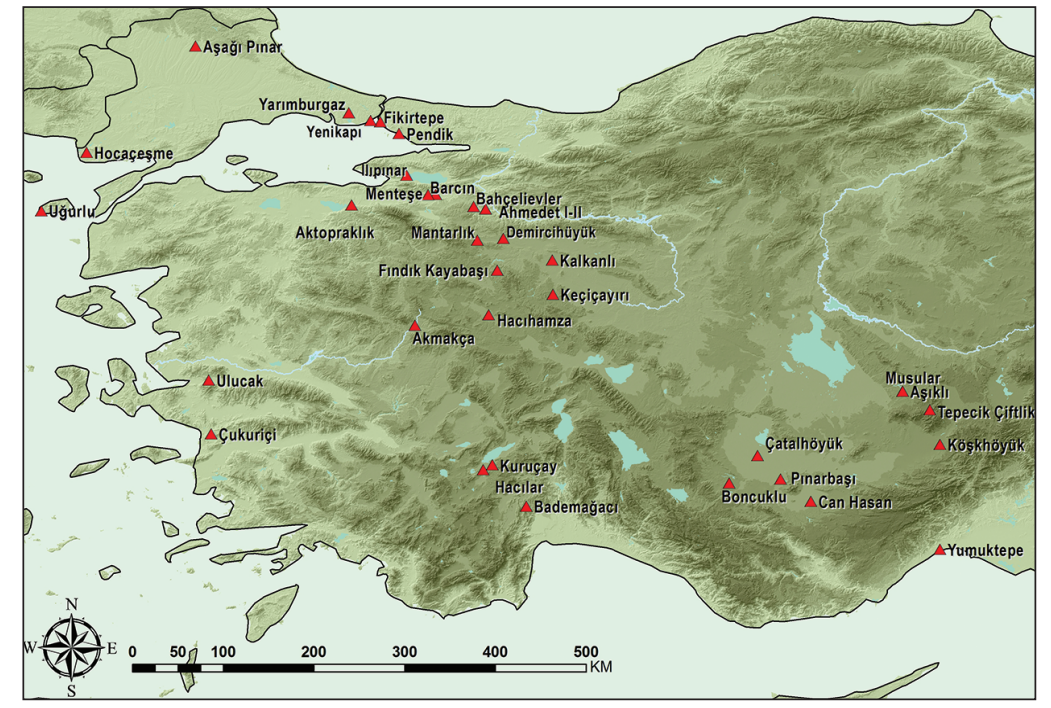

Fig. 1. Major Anatolian Neolithic sites of Western Anatolia.

1 For current ${ }^{14} \mathrm{C}$ dates see http://www.14sea.org. 
the east of the Sea of Marmara (Zone C2). The trend seems to be that the Neolithic lifestyle spread along two paths from the Lakes District, with one continuing south to the Aegean coast and the other crossing the Anatolian Plateau to the Sakarya River basin (Özdoğan M. 2014.36; 2016.54-55).

Recent data has amply demonstrated that Neolithisation is closely connected with climatic oscillations (Weninger et al. 2014). A period of rapid climate change now known as the 8.2-k event saw a period of rapid cooling that lasted up to 600 years, Phase A from 6600 to $6300 \mathrm{BC}$ and Phase B from 6300 to 6000 BC. Phase A corresponds to the period when pottery was used first in the Near East and when a number of Pre-Pottery Neolithic settlements were abandoned (Weninger et al. 2014.13-14). By Phase $\mathrm{B}$, there were a greatly increased number of settlements in Western Anatolia (Özdoğan, Gatsov 1998. 211).

The earliest traces of the pre-Neolithic Period in North-western Anatolia have been discovered in the Chatalca-Kocaeli district to the north of the Sea of Marmara. These appear in sites that reflect the elements of the Ağaçli culture, a late Mesolithic phase from the $8^{\text {th }}$ millennium BC (Özdoğan, Gatsov 1994; 1998.210, 213). The lithic material of this phase is similar to the Neolithic examples that followed, including microlite tools created using pressure techniques reminiscent of the epigravettian tradition, and chipped stone tools with prismatic blade cores. It is probable that the lithic toolkit of the Mesolithic Ağacli culture was adopted by the Neolithic Fikirtepe one (Özdoğan M. 1999.203).

Yet evidence from settlements such as Keçiçayırı, Kalkanl, and Asarkaya situated in the district of Eskişehir shows that some communities followed ceramic traditions that originated from Central Anatolia and used very different chipped stone tool technologies to those living further north. These tools are from contexts that date to the Pre-Pottery Neolithic, and come from a different tradition to the microlilte tools of the Ağaçlı culture of Mesolithic Period, or the Pendik and Fikirtepe cultures that followed. They are characterized by macro blades, macro perforator and chipped discs (Özdoğan, Gatsov 1998. 213-214). Macro blades and macro perforator are closer to the traditions seen in material from the Pre-Pottery Neolithic Period of Konya Plain. This suggests that there were connections with North-western Anatolia during the Pre-Pottery Neolithic (Özdoğan, Gatsov 1998; Efe 2005; Efe et al. 2012).

The chipped stone tools known from the Pre-Pottery Neolithic of the Konya Plain seem to have been part of a long tradition, especially in the eastern parts of the plain in the district of Eskişehir. Keçiçayırı, Kalkanl, and Asarkaya are situated at the western extremity of the culture's distribution area (Efe 2005. 112). These settlements, which contain the first traces of Neolithisation in the area, are located in high, somewhat mountainous areas that are more suitable to hunting and animal husbandry than to agriculture (Özdoğan M. 1997.18).

Traces of pottery appear for the first time in the Konya Plain during the early 7 th millennium $\mathrm{BC}$, in Levels XI-VIII at Çatalhöyük, which have been dated to $7000-6700 / 6600 \mathrm{BC}$. It is represented by strawand grit tempered coarse ware, thick-walled simple profile bowls, and holemouth jars (Özdöl 2006.130153). The earliest traces of pottery in the Lakes District are seen shortly thereafter, in the EN I/8-9 layers at Bademağac1, dated to 7050-6705 BC (Duru 2007.349). By the middle of the $7^{\text {th }}$ millennium BC there were some innovations in the pottery tradition found in Levels VII-IV of Çatalhöyük (6700/6600$6400 / 6300 \mathrm{BC}$ ), which were a development of the earlier styles and have been defined as the 'Middle Tradition' (Özdöl 2006.153-205). Among these developments are the ledge-rimmed bowls, 's'-profile bowls, squat-necked pots, and pierced lugs that became distinctive elements for dating settlements in Western Anatolia. The features of the Middle Tradi-

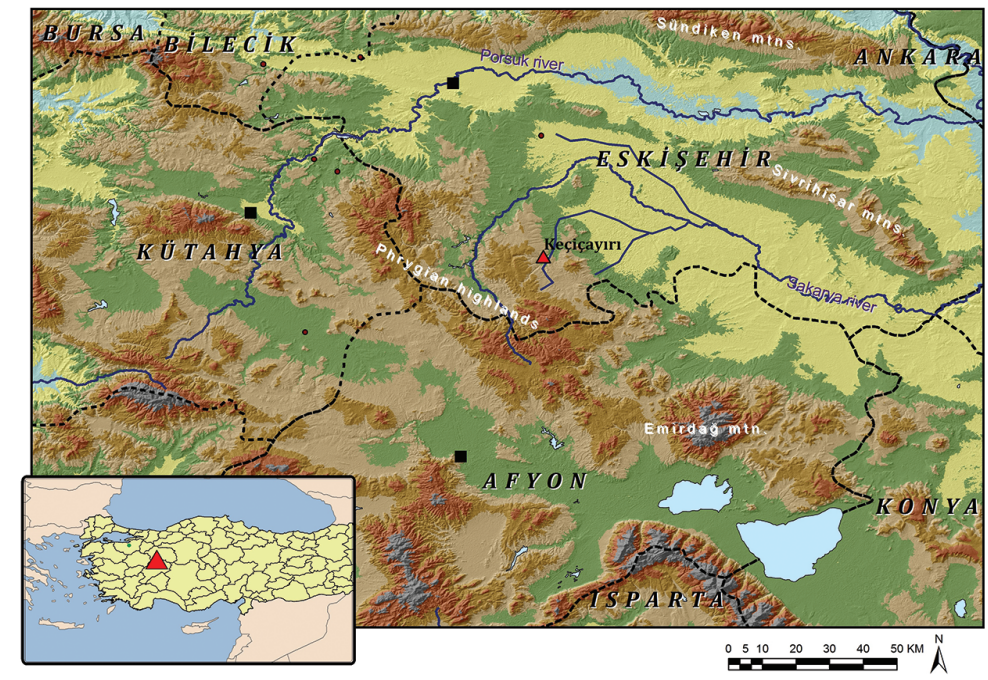

Fig. 2. The location of Keçicayır. 




Fig. 3. Topographical plan and trenches of Keçiçayırı.

tion of the Konya Plain are found in the pottery of Inner North-western Anatolia a few centuries later.

These are the earliest ceramic forms from this region, from a period called the Initial Neolithic (Özdogan E. 2015.51, Fig. 6; 2016.271, Fig. 2; Erdoğu et al. 2015.34). Radiocarbon and relative dates are consistent for the pottery of the western part of the Konya Plain and that of the Inner North-western Anatolia from Keçiçayırı and Demircihöyük, in the district of Eskişehir, and Layers VIe and VId (6570$6330 \mathrm{BC})$ at Barcin, where they have been attributed to a pre-Fikirtepe culture (Gerritsen et al. 2016. 200). Holemouth jars and ledge-rim pots indicate that these ceramics originated in the tradition found earlier at Çatalhöyük. It appears to have arrived on the Aegean coast one or two centuries earlier still, having been dated at Ulucak VI to 6750-6600 BC (Cilingiroğlu 2012.18) and at Çukuriçi XII-XI to approx. 6772-6489 BC (Horejs et al. 2015.302).

In the next phase, the settlements of Menteşe $3 \mathrm{Ba}$ sal and Aktopraklik C were founded to the south of the Sea of Marmara, followed soon after by Fikirtepe and Pendik to its north. This phase began around $6300 \mathrm{BC}$ and corresponds to the Late Neolithic layers III-0 at Çatalhöyük (6400/6300-6000 BC), and has been called the 'Late Tradition' (Özdöl Kutlu
2014). The pottery parallels the Middle Neolithic Period in Northnorth-western Anatolia (Özdoğan E. 2016.Fig. 2), and retains the elements of pottery from the 'Archaic Fikirtepe culture'. These elements include 's'-profile bowls and squat-necked pots also known from the Middle Tradition of Çatalhöyük, along with rectangular or triangular cultic wares with incised decoration known as 'Fikirtepe box' forms.

The Late Neolithic phase began $c .6000 \mathrm{BC}$ and lasted until around $5750 \mathrm{BC}$. It was in this phase that two different cultural regions coalesced in Western Anatolia: the Fikirtepe culture that extends along a region that included the eastern parts of the Sea of Marmara and the Sakarya Basin directly to the southeast, and the Hacilar culture that developed in Southwestern Anatolia and is characterized by a red-oncream pottery tradition.

Fikirtepe ceramics originated in the monochrome tradition of Central Anatolia, which was found across the whole of Western Anatolia in the previous phase, but merged with local elements and developed to take on a new identity. This interpretation is based on surface surveys at the settlements of Akmakça, Findikkayabassı (Efe 1990.409), and Hacihamza (Efe 1994.574) in the western part of the Anatolian plateau, where Fikirtepe pottery, including elements 
such as Fikirtepe box forms, have been found together with red-on-cream wares. As such, the plain of Eskişehir, incuding Demircihöyük, seems to have been at the border between classical Fikirtepe culture and those of the Hacilar culture. Some pieces of typical Fikirtepe wares have been found in surface surveys to the north of this region, such as Ahmedet I-II (Efe et al. 2015.497) and Bahçelievler (Efe et al. 2015.499) in the district of Bilecik, where no traces of painted pottery have been encountered.

\section{The location of Keçiçayırı and its excavation history}

The settlement of Keçiçayırı is located in the mountainous southern part of the province of Eskişehir, in an area known as the Phrygian Highlands (Fig. 2). It lies $5 \mathrm{~km}$ southwest of the village of Bardakç 1 and approx. $18 \mathrm{~km}$ south of Seyitgazi. A stream, the Essen, rises beside the village of Yazllkaya and connects to the Sakarya River after passing Keçiçayırı, flowing through a somewhat rough lowland area surrounded by low mountains. Two rocky hills of Neogene chalk, named Cibirada and Aralıkada, border the plain to the east of the Essen. Quaternary alluviums are located in the vicinity of Cibırada. The Keçiçayır1 settlement area surrounds the western foot of this hill, and its fields lie to the northeast on the plain.

Keçiçayırı was first visited by the head of Eskişehir Museum in 1977, and was officially registered after some illegal excavations by treasure hunters had

\begin{tabular}{|lcccc|}
\hline Periods & $\begin{array}{c}\text { Northwest } \\
\text { fields }\end{array}$ & Mound & Terrace Cibırada \\
\hline Roman & $\mathrm{x}$ & $\mathrm{x}$ & $\mathrm{x}$ & - \\
\hline EBA III & - & - & - & $\mathrm{x}$ \\
\hline Late EBA II & - & - & - & $\mathrm{x}$ \\
\hline Late Chalcolithic & - & - & $\mathrm{x}$ & - \\
\hline Early Neolithic & $\mathrm{x}$ & - & - & $\mathrm{x}$ \\
\hline Aceramic Neolithic & $\mathrm{x}$ & $\mathrm{x}$ & - & - \\
\hline Upper Palaeolithic & $\mathrm{x}$ & - & - & - \\
\hline
\end{tabular}

Fig. 4. The stratigraphy of Keçiçayırı.

been reported to the authorities. It was then examined a few times during surface surveys undertaken by Turan Efe from 1988 to 1995, which included the provinces of Bilecik, Eskişehir and Kütahya, and some materials were collected from it (Efe 1997. 217). From 2006 to 2009, with permission from the General Directorate of Cultural Heritage and $\mathrm{Mu}-$ seums and financial support from The Scientific and Technological Research Council of Turkey (TÜB_TAK; SOBAG Proje No 106K111), rescue excavations were carried out under the direction of the head of Eskişehir Museum and with Efe as the scientific consultant (Efe, Türkteki 2007.75; Efe et al. 2011; Fidan 2016; Efe, Tuna 2017; Sarl 2017).

\section{Stratigraphy and excavation}

Excavations at Keçiçayırı were independently carried out in four different areas (Fig. 3): the Mound, the Terrace, the North-western Fields, and the Hill
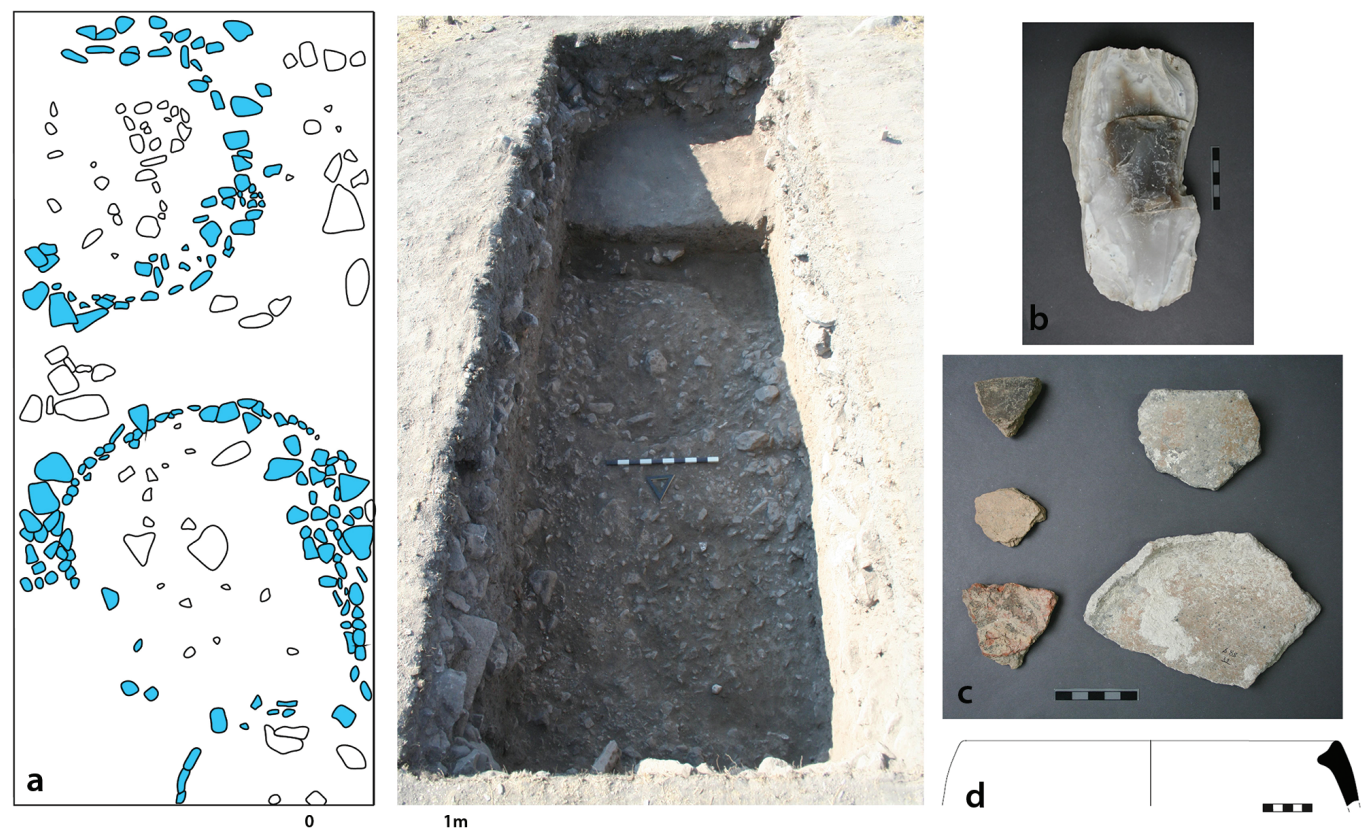

Fig. 5. The flint core dated Pre-Pottery Neolithic and Early Neolithic sherds from trenches other than the Hill of Cibirada. 




Fig. 6. Southern section of the Keçiçayur plain, including Cabrrada and the Mound or Höyük.

of Cibirada (Efe et al. 2011.10). There was a layer of Roman period material on the surfaces of all areas other than the Hill. The excavation areas and the periods they include are shown in Figure 4.

\section{Mound}

The area named the Mound or Höyük is a natural hill, and there was only $50 \mathrm{~cm}$ of cultural accumulation on it. Some stone artefacts that might belong to the Pre-Pottery Neolithic Period were found there, including a discoidal core and end-scrapers (Efe et al. 2012.229, Figs. 5-6), along with remains from the Roman Period. Pits carved into the bedrock at the northern end of a Roman Period building were probably the remains of Pre-Pottery Neolithic Period structures that were demolished during the construction of the Roman one. Many scraps of stone and animal bones were found around these pits ( $E f e$ et al. 2011.11).

\section{Terrace}

A round structure from the Roman Period was found $100 \mathrm{~m}$ northeast of the Mound and approx. 200m southwest of the Hill of Cibirada, and named the Terrace (Efe et al. 2011.12). A sounding opened here reached the bedrock, upon which were two damaged human skeletons. Two vessels, apparently grave goods, were found along with these skeletons, and have been dated to the late Chalcolithic Period (Efe 2008.245).

\section{North-western Fields}

The area called the North-western Fields lies on the plain, approx. $750-800 \mathrm{~m}$ northwest of the Hill of Cibirada. These fields saw extensive use during the Roman Period, but prehistoric remains were reached there in two trenches (b88 and part of b-87). Two supeimposed prehistoric layers were found beneath the Roman ones in trench b-88. The upper layer was homogenous and dark in colour without architecture, while the one below was a pebbly layer containing some chipped stone material. Two round depressions in the pebbly layer might point to an intermediary phase (Fig. 5a). A naviform and a flake core (Fig. 5b) of the Pre-Pottery Neolithic Period are probably the most important finds from this area (Efe et al. 2012. Figs. 3-4), though a few Early Neolithic sherds were also collected from the upper prehistoric layer (Fig. 5c-d), one of which had a ledge-rim and was thus typical of the period (Efe et al. 2011.12-13).

\section{The stratigraphy and Neolithic architecture of Cibirada}

The Hill of Cibirada is situated on the eastern border of the plain, approx. $45 \mathrm{~m}$ higher than the Mound and Terrace (Fig. 6), and the Neolithic and Early Bronze Age (EBA) stratigraphies of Keçiçayırı were obtained from this area. The main settlement at $\mathrm{Cl}$ birada was an EBA fortification, approx. $120 \times 100 \mathrm{~m}$ in size, which was surrounded by a wall that was built to follow the natural contours of the hill. Pottery and other finds from the settlement show that it dates to the second half of the $3^{\text {rd }}$ millennium BC (Efe, Tuna 2017; Fidan 2016; Sar 2017).

Two EBA II structures, named Rooms 15 and 16, were found in squares AV-1, AY-1 and AZ-1 in the



Fig. 7. The Neolithic layer under the EBA II houses of the citadel (Room 15 and 16) situated on the Hill of Cibirada. 


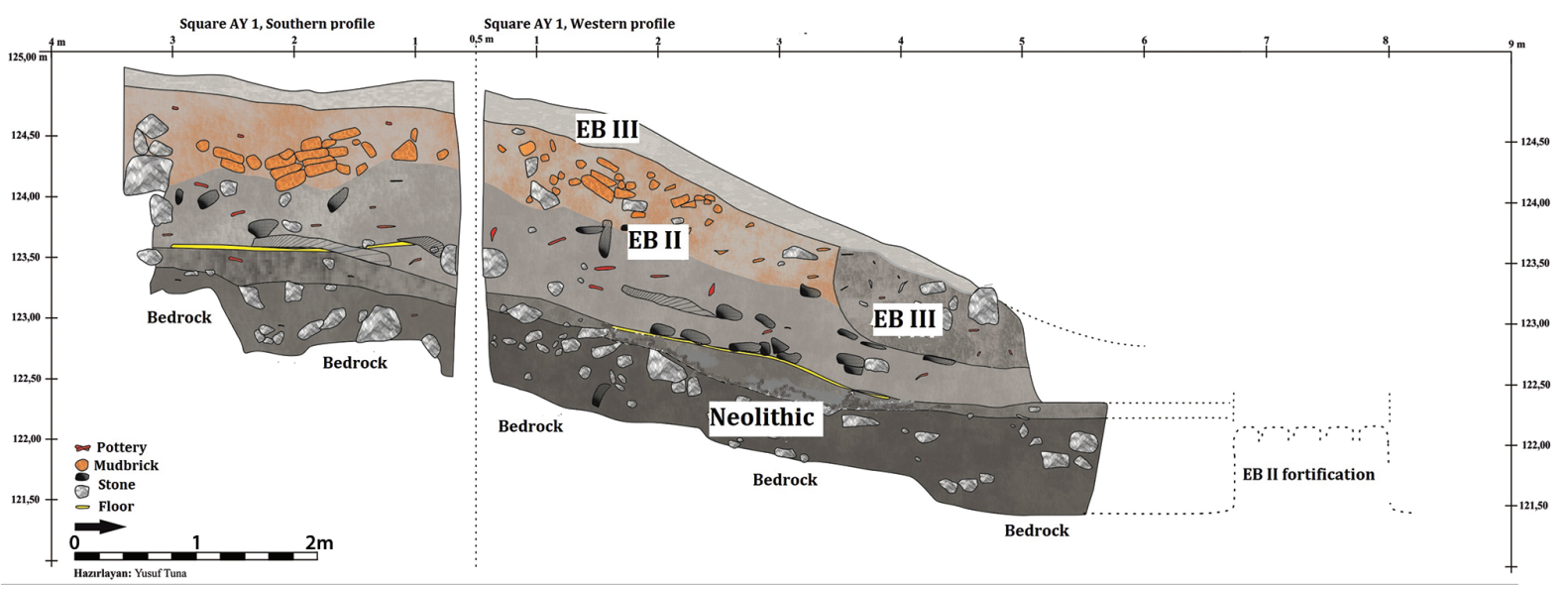

Fig. 8. The stratigrapgy of Cuburada, Trench AY 1, western and southern profiles, Room 15.

north of the settlement (Fig. 7). They appear to have been destroyed in a fire. Beneath a thin homogeneous layer containing a mixture of EBA II and Early Neolithic material, there is a Neolithic layer on the bedrock (Fig. 8).

The structures were defined by three north-south walls, built directly onto the bedrock and following the slope of the hill, so that the northern end was approx. $50 \mathrm{~cm}$ lower than the southern one. Overlain by these walls was the only architectural remains of the Neolithic Period to be found, a structure with a round or oval plan carved into the bedrock and approx. $60 \mathrm{~cm}$ in depth and $5 \mathrm{~m}$ in diameter (Fig. 9).

The majority of this structure is still beneath the EBA II walls, but part of its southern extent was revealed during excavation. It consisted of two courses of small- to medium-sized stones surrounding a pit that had been cut into the bedrock. No traces of mudbrick or post-holes were found, but the soil matrix contained pottery and many ground- and chipped stone tools were discovered lying in situ on the bedrock.

Chipped discs made from tabular flint, retouched blades, and end-scrapers were found with pottery from the Early Neolithic Period on the Hill of Cib1rada (Fig. 10). These tools were generally shaped by indirect percussion, though direct percussion was also used for flakes (Gatsov et al. 2016.2). The pressure flaking which was de- veloped from the previous Pre-Pottery Neolithic phase is used subsequently for bullet core fragments; this connects the Konya plain with Keçiçayırı and Barcin VIe-VIe/d (Gatsov et al. 2016.3) and then to Aktopraklık C (Karul 2017.66-67; Özdoğan M. 2014.42, Fig. 7) to the south of the Sea of Marmara. The Early Neolithic pottery assemblages from Keçiçayırı, discussed in greater detail in the sections that follow, also support this opinion.

\section{The Neolithic pottery of Keçiçayırı}

Neolithic pottery had been found in square b-88 in the North-western Fields and in squares AV-1, AY-1, and AZ-1 on the Hill of Cibirada. The number of pieces in North-western Fields was limited, with only eight body sherds and one ledge-rim piece that might be dated to the Neolithic Period being found in this area (Fig. $5 \mathrm{c}-\mathrm{d}$ ). The Hill of Cibirada yielded a greater number, and 522 pieces dating to this period and

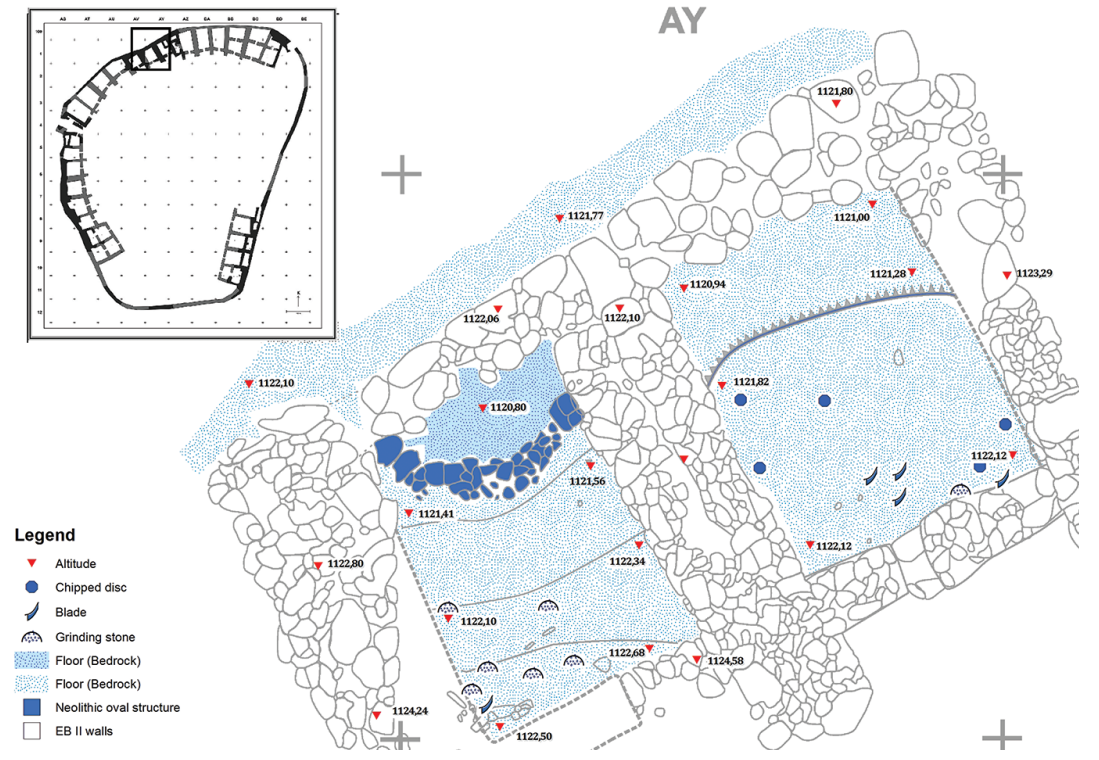

Fig. 9. Neolithic layer of Cubırada (Rooms 15 and 16). 
55 of the assemblage are diagnostic. These were found across an area of roughly $100 \mathrm{~m}^{2}$, in strata that were on average $60 \mathrm{~cm}$ deep.

\section{The ware groups}

The 522 Neolithic sherds have been identified as belonging to three main ware groups: Red Slipped Wares, Dark Faced Wares, and Coarse Wares. Coarse Wares represented $60 \%$ of the pottery, and are thus the most common ware group from the settlement, though most were amorphous pieces. Dark Faced Wares were the next most common, at 35\%, while Red Slipped Wares were sparsely represented, at only $5 \%$. There is, however, a margin of error because it was not always easy to distinguish which pieces might belong to a given ware group (Fig. 11).

\section{Red Slipped Wares}

The surfaces of Red Slipped pieces were better preserved than those of the other ware groups due to their slip and burnishing. The surface colours were typically red and reddish brown, though in some pieces the colour was closer to a shade of brown. Some pieces were speckled due to secondary combustion. The paste was more readily observable than in Coarse and Dark Faced Wares, though no cores were found. Mica was commonly used as a temper, but thin or gritty straw tempers were also visible (Fig. 12a). Red Slipped ware was mainly used for simple profile bowls, 's'-profile bowls, closed vessels, and long necked pots.

\section{Dark Faced Wares}

This group was only the second most commonly represented group of Neolithic pottery, but 43 of the 55 diagnostic pieces (78\%) were Dark Faced Ware. Blemishes on the surface were generally corrected by non-slipped plaster that was burnished to varying degrees. Accordingly, some pieces have smooth and bright surfaces, while others have matte surfaces that are less well-finished. A variety of dark browns were dominant among the surface colours, but there were light-brown faced pieces as well, and some had multiple colours due to secondary combustion. The paste was generally mid-brown, though some samples were beige and dark brown, while others had a grey or black core. Mica was used as a temper in almost every piece, and could be seen on the surfaces of some. Thin grit temper was used in thin-walled wares, and rough grit and some straw temper in thick-walled wares (Fig. 12b). A variety of forms were observed, including simple profile bowls, ledge-rim bowls, 's'-profile bowls, closed vessels, squat necked pots, long necked pots, and lids. Verti-

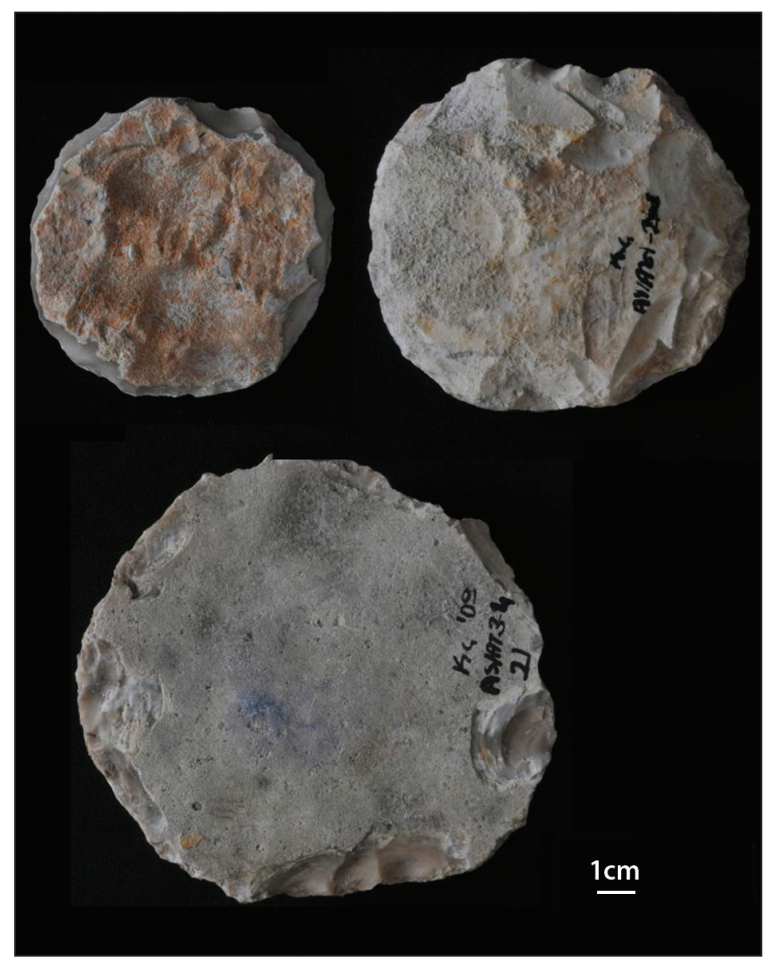

Fig. 10. Chipped-discs from Cibirada.

cal handles, horizontal handles, vertical lugs and pierced lugs were seen.

\section{Coarse Wares}

The surfaces of Coarse Wares were not generally well-finished, and slip and burnish were not used on this ware group. Some $72 \%$ of these pieces were multi-coloured in grey and black due to secondary combustion, so although it is not easy to determine the original colour of this ware type it is almost certain that dark colours were dominant, albeit that some light brown/beige shades were seen. The colour of the paste also ranged from shades of light brown/beige to dark brown/black, with some samples showing light grey pastes and black cores. Rough grit, mica, and limestone were used as inclusions. Straw-based tempers were seen but were uncommon, though many samples showed straw negatives on the surface (Fig. 12c). So far as it is possible to determine, the majority of Coarse Ware pieces were storage- and kitchen wares. Almost all of the pieces found were body sherds, with only three base pieces that might be considered diagnostic.

\section{Pottery forms}

The amount of pottery obtained from the Neolithic layer is not high, and the diagnostic sample is limited. Most of the Early Neolithic pottery from Keçiçayır1 can be reconstructed as bowls and jars, along with a handful of lids and handles (Fig. 13). 


\section{Bowls}

As noted, most of the bowl forms at the settlement (P1. 1.1-10) were of Dark Faced Ware, along with a few of Red Slipped Ware. They have been subdivided typologically into three groups: simple profile bowls (Fig. 13.1a), ledge-rim bowls (Fig. 13.1b), and 's'-profile bowls (Fig. 13.1c).

Simple profile bowls made up 30\% of the Neolithic bowls, most of which were of Dark Faced Ware. Their profiles either show a slight outward curve or are vertical (P1. 1.1-3). Ledge-rim bowls have a broadly similar form, but have an internal ledge around their rims, which probably allowed a lid or cover to be placed on them (P1. 1.4-7). All of the ledge-rim bowls at Keçiçayırı were Dark Faced Ware. 'S'-profile bowls (P1. 1.8-10) also made up 30\% of the bowls at the settlement, and most were Dark Faced Ware but a few Red Slipped Ware samples were seen. The mouths and body parts of 's'-profile bowls were normally well-finished, though some were quite rough.

\section{Jars}

There were two subgroups of jar - closed jars and necked jars - the surfaces of which were generally dark and burnished. The majority of the base and body sherds from the settlement were jars. Closed jars (Fig. 13.2a) were the most common type, making up $65 \%$ of all forms of jar at the settlement. This form narrows at the mouth, which has a horizontal profile, and normally a globular body, and is one of the characteristic forms of the Neolithic Period (P1. 1.11-13, Pl. 2.14-21). Closed jars were probably used for storage. The majority were again Dark Faced Ware, with a limited number of Red Slipped Ware examples.

Necked jars (Fig. 13. 2b) differ from closed jars in that a neck arches upward from the body (Pl. 2.2227). The majority of these rims were of Dark Faced Ware, with Red Slipped Ware in limited numbers. Necked jars have two subgroups according to the length of the necks: 'squat' necked jars (Fig. 13.2b1; P1. 2.22-24) and 'long' necked jars (Fig. 13.2b; Pl. 2.25-27). Some 'long' necked jars also had vertical handles (Pl. 4.51).

\section{Lids}

Covers or lids were probably used with ledge-rim bowls or on cooking vessels. The surfaces of the samples found at Keçiçayırı were well burnished and all of them were of Dark Faced Ware. One of was $15 \mathrm{~cm}$ and another was $17 \mathrm{~cm}$ in diameter. This form does not show much variety, having sharp edges and rising in the centre to form a low dome (Pl. 4.47-48).

\section{Handles, lugs, and bases}

All examples are Dark Faced Ware. Handles are vertical (Pl. 4.51) or horizontal (Pl. 4.49). Lugs are vertical (P1. 4.50) and some of them are pierced (P1. 4.52-54). Bases were the most common diagnostic in the sample (Fig. 11), comprising nearly half of the Dark Faced Ware and Coarse Ware, though two Red Slipped Ware base sherds have been found. All bases should be regarded as belonging to jar forms due to ware, base types, rising angles, and diameters. Some
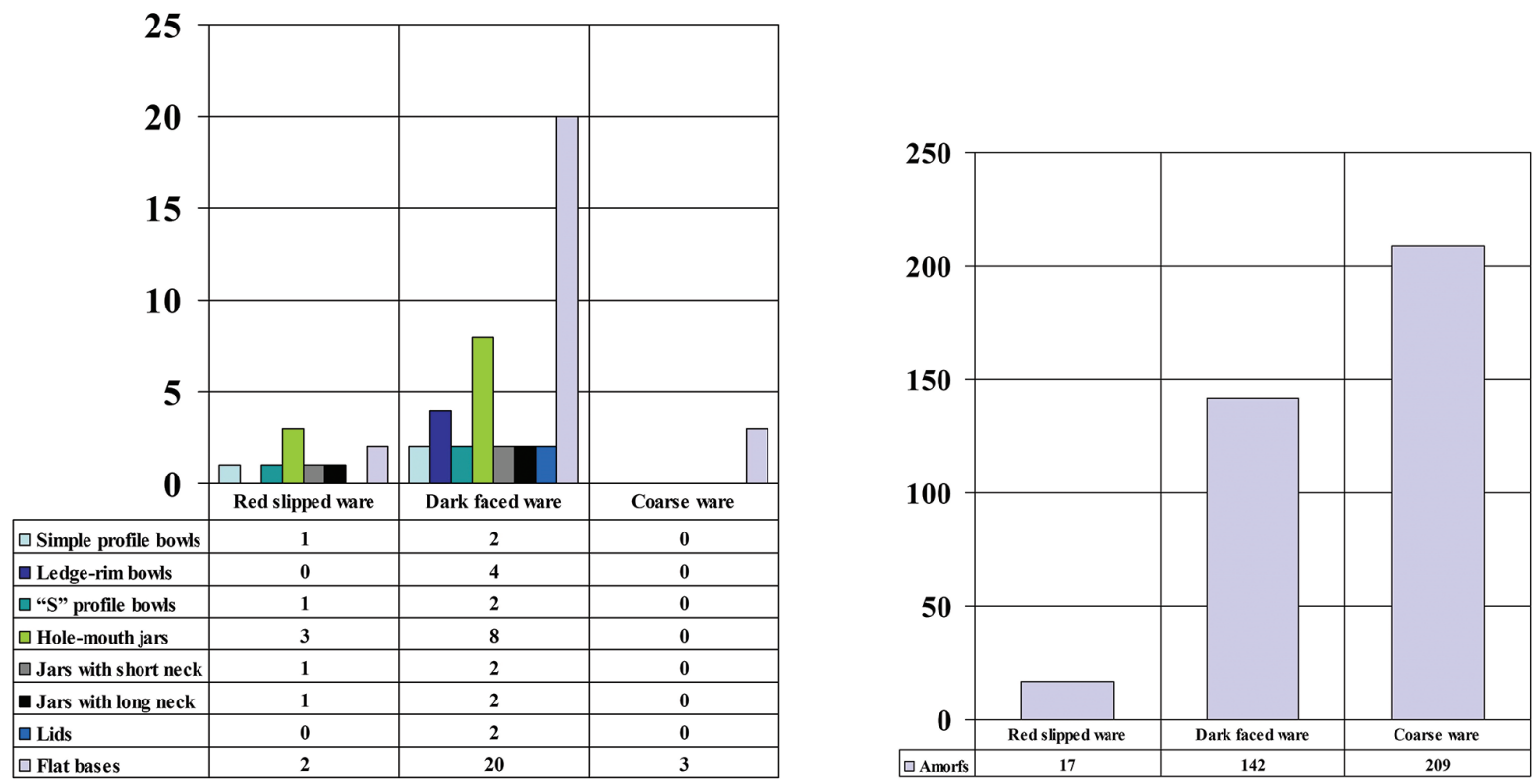

Fig. 11. The ratio of the ware groups. 


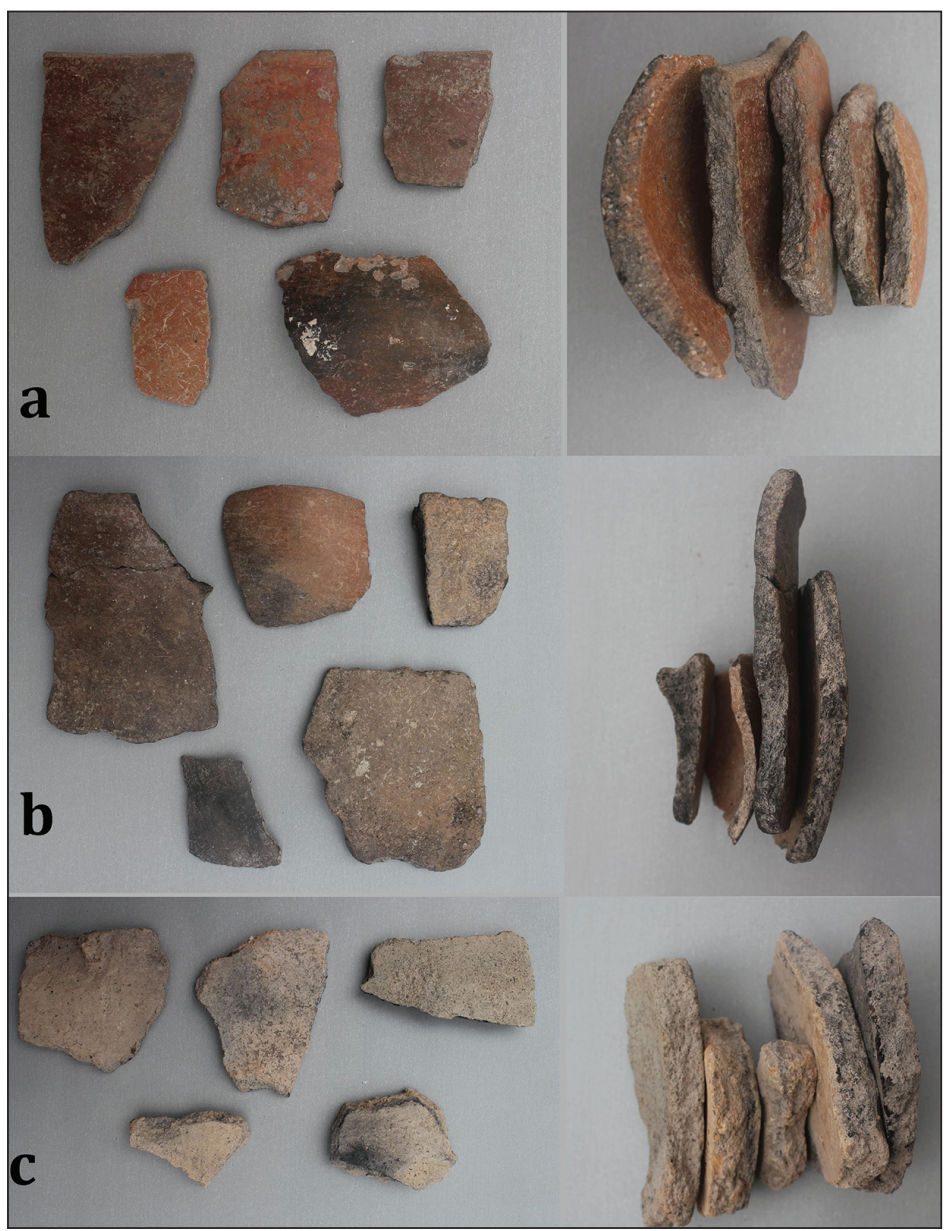

Fig. 12. Ware groups.

of the bases were very rough and thick, though there were also some that were thinner, and more care had been taken during their manufacture.

\section{Comparisons with other sites}

Although the short-term rescue excavations conducted at Keçiçayırı allowed important archaeological data to be retrieved, it was not possible to take advantage of radiocarbon dating methods to produce an absolute chronology. Comparative chronologies are possible, however, notably with Çatalhöyük, one of the starting points for Neolithisation in Western Anatolia, but also with Demircihöyük in the far west of the Plain of Eskisehir, some $90 \mathrm{~km}$ northeast of Keçiçayırı, and with Barcın Höyük in the Plain of Yenişehir, $180 \mathrm{~km}$ from Keçiçayırı in the same direction. The radiocarbon data taken from stratigraphic levels at Barcın Höyük is particularly significant for the chronology of Keçiçayır1.

\section{Catalhöyük}

The pottery of Keçiçayırı can be seen as a development and variety of the pottery from levels VII-IV at Çatalhöyük, where the most common groups are straw tempered dark wares, dark faced burnished wares, and grey granular red-slipped wares (Özdöl 2006. 154). The dark faced wares and red slipped wares with grey scrapings on them are similar to those from Keçiçayırı both in terms of paste and surface treatment. The pottery from level III at Çatalhöyük shows that dark faced wares continue from previous levels but also see a decrease, with lighter and red surfaces taking their place (Özdöl 2006.161).

Vessel walls became thinner at Çatalhöyük from level VIII, and from level VII there was an increase in form types and ware groups. Closed vessels continued to develop from previous levels (Özdöl 2016.Pl. 25), particularly in level VI ( $\ddot{O} z$ döl 2006.Pl. 24) where they are a good match with those from Keçiçayırı. Simple profile bowls continued into levels VII-IV, again developing from previous phases. Ledge-rim bowls appear in level VI (Özdöl 2006.Pl. 31.2, 32.2-3, 33.3, $36.3,37.2-3)$, and are very similar to those at Keçiçayırı. Pierced lugs also appear in level VI. These forms appearing in levels VII and especially VI continued to develop through to level III, where 's'-profile and external rim bowls take the place of the closed vessels commonly seen from level XI (Özdöl 2006.Pl. 126).

\section{Demircihöyük}

Ware A, a mica schist tempered and red-slipped ware from Demircihöyük, is believed to correspond to levels XII-IX of Çatalhöyük, and Ware B, which has intense mica temper, grey- to greyish-beige faces, and shining surfaces due to this mica temper, corresponds to levels IX-VI. The forms represented among Ware A include ledge-rims (Seeher 1987.Pl. 1.1-7), closed mouths (Seeher 1987.Pl. 1.8-9), lids (Seeher 1987.Pl. 1.16-19), horizontal lugs (Seeher 1987.Pl. 1.10) and straight bases (Seeher 1987.Pl. 1.11-15). Different forms are known from Ware B at Demircihöyük, including necked pots (particularly the 'squat' necked subgroup; Seeher 1987.Pl. 2.12, 15-18), 'S'profile bowls (Seeher 1987.Pl. 3.4-5) and pierced lugs (Seeher 1987.Pl. 2.11).

\section{Barcın Höyük}

Finds from phase VIe, the earliest Neolithic phase at Barcin Höyük (c. 6570 BC), have been compared to 
those from Demircihöyük Ware B and appear to predate level VI at Çatalhöyük (Gerritsen et al. 2013.73). The pottery of Barcin VIe is represented by simple profile bowls and closed vessels (Gerritsen et al. 2013.Fig. 17.1-7), while one of the more notable forms found in phase VIe has been identified as a prototype for Fikirtepe box forms (Gerritsen et al. 2013.Fig. 17.9-10). The first ledgerim bowls appear at the transition between phases VIe and VId, alongside profile bowls and closed vessels (Gerritsen et al. 2013.Fig. 18.1-5), as do 's'-pro-


$1 \mathrm{c}$

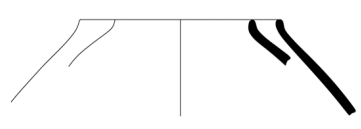

$2 \mathrm{~b} 1$

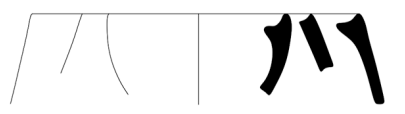

$1 \mathrm{~b}$


$2 \mathrm{~b} 2$

Fig. 13. The typology of the Neolithic pottery from Keçiçayurt. file bowls, necked pots, and pierced lugs (Gerritsen et al. 2013.Fig. 18.6-15). A painted and decorated vessel, and samples of four-footed and incrusted Fikirtepe box forms (but without white paste fill) were also among the new forms from the Barcin phase VId (Gerritsen et al. 2013.Fig. 19.7-8).

\section{Aktopraklık}

Aktopraklık is located in Akçalar, 4km east of Lake Ulubat and approx. $30 \mathrm{~km}$ from Bursa. It is situated at the western edge of a corridor running from Eskişehir to Bozüyük and Bursa that connects Central Anatolia to the northwest (Karul 2017.81). The earliest settlement was in Area $\mathrm{C}$, and its earliest phases, which have been dated between 6380 and 6250 $\mathrm{BC}$, have architecture that consists of round- or oval wattle and daub buildings with a sunken floor. The walls are sometimes supported by a line of stone from the lower end (Karul 2017.90, Fig. 53). Despite the fact that wattle and daub superstructure is not evidenced in Keçiçayırı, Aktopraklık is the closest parallel of oval structure carved into the bedrock found at Cibırada of Keçiçayırı. Closed vessels, ledge-rim pots (Avcr 2010.Pl. 18), 's'-profile bowls, and pierced lugs (Karul 2017.92, Fig. 56) were also found in this phase at Aktopraklık.

\section{Relative chronology}

Light faced coarse wares were common in the earliest levels at Çatalhöyük, but disappeared at the end of level VII, after which dark faced wares became dominant. The pottery from level VI at Çatalhöyük closely resemble those at Keçiçayırı, when ledge-rim pieces, pierced lugs, and especially closed vessels and 'squat' necked pots started to appear. The earliest samples of 's'-profiles are from levels VI and III of Çatalhöyük, and became more developed in level II, and this suggests that the settlement of Keçiçayırı was roughly contemporary with levels III and II of Çatalhöyük.

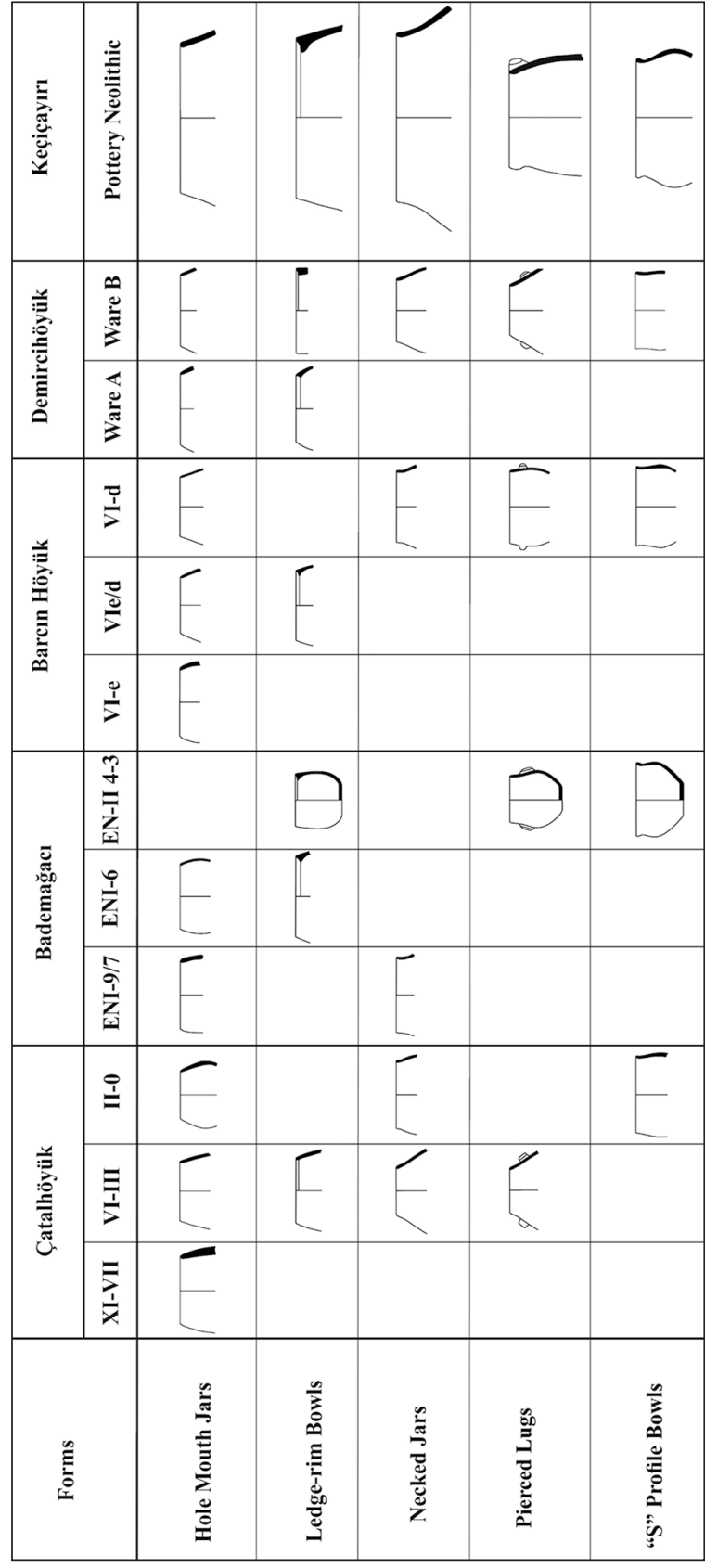

Fig. 14. Form comparison. 
Wares A and B of Demircihöyük do not show many similarities with the ware types at Keçiçayırı, but almost all forms in the Demircihöyük A show parallels with those from Keçiçayırı. Most notable are the ledge-rims and closed vessels, which imply that Keçiçayırı was contemporary with the Ware A at Demircihöyük, while the existence of 's'-profiles, one of the most characteristic forms of Demircihöyük Ware B, indicates that settlement at Keçiçayırı continued into this phase.

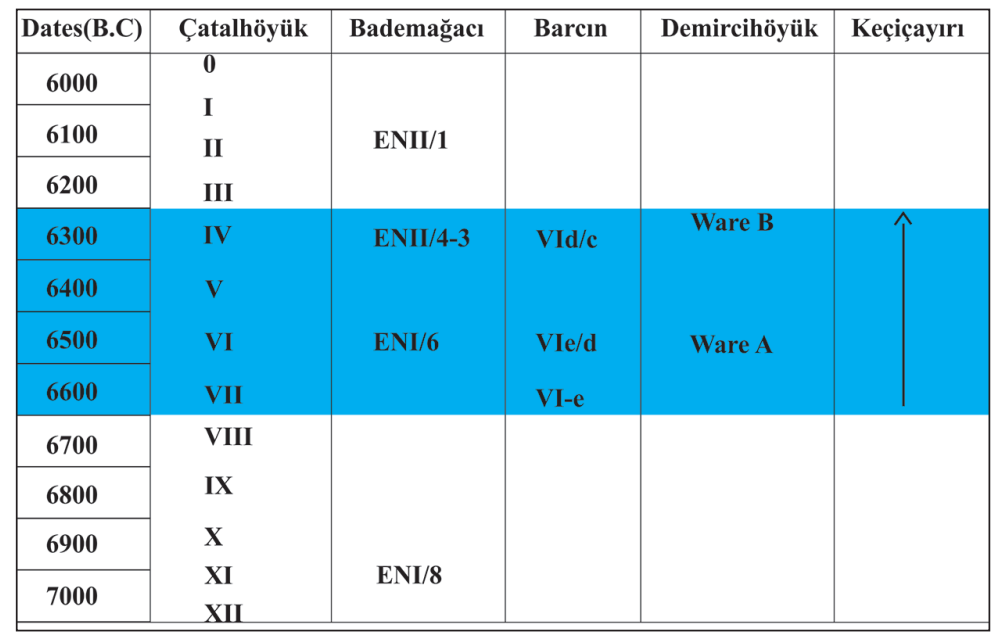

Light coloured wares dominate the earliest level of Barcın Höyük, level

Fig. 15. The suggested chronology of Keçicayır.

VIe, and these are reminiscent of the coarse wares at Keçiçayırı, albeit that the latter lacks diagnostics. Dark faced wares began to appear at the transition between phases VIe and VId at Barcın Höyük, and these show many similarities with those from Keçiçayırı. Notably, the walls of ledge-rim vessels and closed vessels from phase VId became thinner, paralleling the repertoire of ware and form at Keçiçayırı. These data suggest that Keçiçayırı was settled concurrently with Barcin Höyük phase VIe. Additionally, the 's'-profile bowls, necked pots, and pierced lugs that appeared in phase Barcin VId and continued into phase VIc show Keçiçayırı was still occupied at this time. Similar elements seen in the early stages of Aktopraklık C imply that it was also settled at this time, as do the oval structures, which further suggest cultural connections with Keçiçayırı.

Pottery of Phase VId at Barcin shows similarities with Keçiçayırı, but there are also differences. The painted and decorated sherds found here and the incrusted Fikirtepe box differ from anything found at Keçiçayırı, though a non-decorated Fikirtepe box was found at Keçiçayırı during an early surface survey (Efe 2005.Fig. 8). Comparative data and a suggested chronology are presented in fgures 14 and 15.

\section{Conclusions}

While the Ağaçlı culture was present on the Bosphourus and Western Black Sea coasts during the Mesolithic Period, there is no evidence for settlements to the south of the Sea of Marmara or in inland western Anatolia, where Keçiçayırı is located. As the area transitioned into the next phase, traces of Pre-Pottery Neolithic at lasting settlements - which had a longer tradition in the east of the Konya Plain - begin to appear along the natural route that connects Central Anatolia to Eskissehir and then to Southern Marmara. Keçiçayırı is one such settlement, and along with the introduction of pottery it had a different lithic tradition to that of the previous Ağaçlı culture, such as macro blades and chipped discs. Its location at the easternmost point of the corridor from the Anatolian plateau to the Sea of Marmara is consistent with its place in the Neolithisation process of Northwestern Anatolia.

During the first half of the $7^{\text {th }}$ millennium BC, the occurrence of pottery influenced by the western part of Konya Plain appeared in this area, signifying the beginning of the Early Neolithic Period in Northwestern Anatolia. This early pottery seems to have spread quite rapidly, appearing within a few centuries in areas along the south-eastern coast of the Sea of Marmara, and then its northern coast. In this context, it can be shown that Keçiçayırı was settled during the period concurrent with Çatalhöyük VI-IV and with Barcın Höyük layers VIe to VId. It can therefore be dated to $6700 / 6600-6300 \mathrm{BC}$, after which time it was abandoned.

The results of the research outlined above are demonstrated by what might be the earliest Neolithic architecture among the highlands along this corridor, on the Hill of Cibırada at Keçiçayırı, represented by a stone architecture with round structures dug into the bedrock. This architecture was accompanied by many grinding stones, chipped stones, and blades found in situ, as well as pottery from a monochrome tradition that included holemouth jars, simple profile bowls, ledge-rim bowls and jars, 's'-profile bowls, necked jars, pierced-lugs, and prototypes of the socalled Fikirtepe boxes. This ceramic tradition origi- 
nated on the Konya Plain, and became common on the whole of Western Anatolia during the Early Neolithic, including Northwestern Anatolia, the Lakes District, and the Aegean Coast.

Regional differences had not yet begun to be form at this time. This process began around 6300 $\mathrm{BC}$, as the Lakes District in the south began to adopt a painted pottery tradition, perhaps influenced by further away, from the Eastern Mediterranean. But there is no evidence of such an influence in North-western Anatolia, and it is here that the Early Neolithic monochrome pottery from the Konya Plain continued to



Fig. 16. The spread of the Neolithic from Central Anatolia to the Western Anatolia. develop, becoming integrated with local elements and finally transforming into Fikirtepe culture. The lack of evidence for these later cultural elements at Keçiçayırı suggests that settlement there came to an end just before these regional cultures, or the Archaic Fikirtepe culture, developed. Accordingly, it may be claimed that Keçiçayırı was settled roughly between 6600 and $6300 \mathrm{BC}$. This period corresponds to the first stage of the Neolithic expansion to the Western Anatolia. There was no longer an occupation at Keçiçayırı around 6300 to $6000 \mathrm{BC}$, but there were settlements in the northern part of the Eskissehir plain (Demircihöyük, Ahmedet I-II, Bahçelievler) and the eastern part of the Sea of Marmara, some of which
(Barcın, Aktopraklık, Pendik, Fikirtepe, Yenikapı) were newly established (Fig. 16).

The settlement of Keçiçayırı shows that Neolithic communities, which were previously founded on plains and coastlines, could also be established in mountainous (but sheltered) areas. The model of settling on a hill was often preferred during the Chalcolithic Period, as settlements such as Orman Fidanlığı, Kanlıtas and Keskaya indicate. The hill settlement at Keçiçayırı in the Early Neolithic Period shows that this tradition existed before the Chalcolithic in the region. 


\section{References}

Avcı M. B. 2010. Aktopraklık Verileri Işı̆ı̆nda Doğu ve Güney Marmara'da Fikirtepe Çanak Cö̈mleğinin Gelisim Süreci. Master's thesis. Istanbul University. Istanbul.

Çilingiroğlu C.. 2012. The Neolithic Pottery of Ulucak in Aegean Turkey. British Archaeological Reports IS 2426. Archaeopress. Oxford.

Duru R. 2007. Göller Bölgesi Neolitiği. In M. Özdoğan, N. Başgelen (eds.), Anadolu'da Uygarlı̆̆ı Doğuşu ve Avrupa'ya Yayılımı. Türkiye'de Neolitik Dönem: Yeni Kaztlar, Yeni Bulgular. Arkeoloji ve Sanat Publications. Istanbul: 331-360.

Efe T. 1990. 1988 Yılında Kütahya, Bilecik ve Eskişehir İllerinde Yapılan Yüzey Araştırmaları. Araştırma Sonuçlari Toplantısi VII: 405-424.

1994. 1992 Yılında Kütahya, Bilecik ve Eskişehir Illerinde Yapılan Yüzey Araştırmaları. Araştırma Sonucları Toplantısı XI: 571-592.

1997. 1995 Y1lında Kütahya, Bilecik ve Eskișehir illerinde Yapılan Yüzey Araştırmaları. Araştırma Sonuçları Toplantısı XIV: 215-232.

2005. Neolitization in Inland Northwestern Anatolia. In L. Clemens (ed.), How Did Farming Reach Europe? BYZAS 2. Ege Publications. Istanbul: 107-115.

2008. Keçiçayrı'nda Ölü Hediyesi Olarak Bulunmuş Olan İki Geç Kalkolitik Kap. In Taner Tarhan, Aksel Tibet, and Erkan Konyar (eds.), Muhibbe Darga Armağan. Sadberk Hanım Müzesi Publications. Istanbul: 243250.

Efe T., Gatsov I., and Nedelcheva P. 2012. The Neolithic Settlement of Keçiçayırı near Seyit gazi, Eskişehir. In M. Özdoğan, N. Başgelen, and P. Kuniholm (eds.), The Neolithic in Turkey: New Excavations \& New Research. Vol. 4, Western Turkey. Arkeoloji ve Sanat Publications. Istanbul: 227-236.

Efe T., Sarı D., and Fidan E. 2011. The Significance of the Keçiçayırı Excavations in the Prehistory of Inland Northwest Anatolia. In N. Bilgen, R. von den Hoff , S. Sandalc1, and S. Silek (eds.), Archaeological Research in Western Central Anatolia. The IIIrd International Symposium of Archaeology. Dumlupınar University Press. Kütahya: 9-28.

Efe T., Tuna Y. 2017. Frigya Yaylası'nda Yer Alan Keçiçayırı Yerleşmesinde Ele Geçirilen İk Tunç Çağı Çanak Çömleği. Arkeoloji Dergisi XXII: 49-116.
Efe T., Türkteki M. 2007. Keçiçayırı (Seyitgazi-Eskişehir) 2007 Y1lı Kurtarma Kazıları. Colloquium Anatolicum VI: 75-84.

Efe T., Türkteki M., Sarı D., and Fidan E. 2015. Bilecik İli 2013 Yılı Yüzey Araștırması. XXXII. Kazı Sonuçları Toplantrsi 1: 495-504.

Erdoğu B., Çevik Ö. 2015. Batı Anadolu Kronolojisi ve Terminolojisi: Sorunlar ve Öneriler. Anadolu Prehistorya Araştırmaları Dergisi/Journal of Anatolian Prehistoric Research 1: 29-48.

Fidan E. 2016. Keçiçayırı: An Early Bronze Age II Fortified Hilltop Settlement (Northwest Anatolia). Mediterranean Archaeology and Archaeometry 16(1): 71-83. https://doi.org/10.5281/zenodo.35523.svg

Gatsov I., Nedelcheva P. 2011. Lithic Artefacts from the Neolithic Period in NW Anatolia. Last results. In N. Bilgen, R. von den Hoff, S. Sandalc1, and S. Silek (eds.), Archaeological Research in Western Central Anatolia. The IIIrd International Symposium of Archaeology. Dumlup1nar University Press. Kütahya: 1-8.

Gatsov I., Nedelcheva P. 2016. Earliest Lithic Material from Keçiçayırı Site, Central NW Anatolia and Barcın Höyük, NW Anatolia. Anatolian Metal VII: 95-98.

Gérard F., Thissen L. 2002. The Neolithic of Central Anatolia: Internal Developments and External Relations During the $9^{\text {th }}-6^{\text {th }}$ millennia cal BC. Proceedings of the International CANeW Table Ronde, Istanbul, 23-24 November 2001. Ege Publications. Istanbul.

Gerritsen F. A., Ozbal R., and Thissen L. C. 2013. The Earliest Neolithic Levels at Barcin Höyük, Northwestern Turkey. Anatolica 39: 53-92.

Gerritsen F. A., Özbal R. 2016. Barcın Höyük and the PreFikirtepe Neolithisation of the Eastern Marmara Region. Anatolian Metal VII: 199-208.

Horejs B., Milić, B., Ostmann F., Thanheiser U., Weninger B., and Galik A. 2015. The Aegean in the Early $7^{\text {th }}$ Millennium BC: Maritime Networks and Colonization. Journal of World Prehistory 28(4): 289-330. https://doi.org/10.1007/s10963-015-9090-8

Karul N. 2017. Aktopraklı: Tasarlanmıs Prehistorik Bir Köy. Ege Publications. Istanbul.

Özbaşaran M., Cutting M. 2007. Orta Anadolu'da Neolitiğin Ortaya Çıkışı ve Gelişimi (Aşıklıhöyük-Çatalhöyük). In 
N. Başgelen (ed.), 12000 Yıl Önce: Uygarlı̆̆ın Anadolu'dan Avrupa'ya Yolculuğunun Başlangıcı Neolitik Dönem. Yap1 Kredi Publications. Istanbul: 55-62.

Özdoğan E. 2015. Current Research and New Evidence for the Neolithization Process in Western Turkey. European Journal of Archaeology 18(1): 33-59.

https://doi.org/10.1179/1461957114Y.0000000079

2016. Diversity and Homogeneity Among the Early Farming Communities of Western Anatolia. Documenta Praehistorica 43: 265-282.

https://doi.org/10.4312/dp.43.13

Özdoğan M. 1997. The Beginning of Neolithic Economies in Southeastern Europe: An Anatolian Perspective. Jour nal of European Archaeology 5(1): 1-33.

1999. Neolithic in Turkey. Arkeoloji ve Sanat Publications. Istanbul.

2007. Marmara Bölgesi Neolitik Çă̆ Kültürleri. In M. Özdoğan, N. Başgelen (eds.), Anadolu'da Uygarlı̆̆n Doğuşu ve Avrupa'ya Yayılımı. Türkiye'de Neolitik Dönem: Yeni Kazılar, Yeni Bulgular. Arkeoloji ve Sanat Publications. Istanbul: 401-426.

2014. A New Look at the Introduction of the Neolithic Way of Life in Southeastern Europe. Changing Paradigms of the Expansion of the Neolithic Way of Life. Documenta Praehistorica 41: 33-49.

https://doi.org/10.4312/dp.41.2

2016. Neolitik Dönem ve Göç - Arkeolojik Veriler Aç1sindan Bir Değerlendirme. Aktüel Arkeoloji 54: 48-59.
Özdoğan M., Gatsov I. 1994. Some Epi Paleolithic Sites from NW Turkey Agacli Domali and Gumusdere. Anatolica $X X: 97-120$.

Özdoğan M., Gatsov I. 1998. The Aceramic Neolithic Period in Western Turkey and in the Aegean. Anatolica XXIV: 209-232.

Özdöl S. 2006. Anadolu'da Erken Neolitik Dönem çanak çömlek kültürleri ve Çatalhöyük örneği. Unpublished PhD Thesis. Ege University. Izmir.

Özdöl Kutlu S. 2014. Reconsidering the Late Neolithic Pottery of the Anatolian Plateau: Current Evidence from Çatalhöyük. Türkiye Bilimler Akademisi Arkeoloji Dergisi 17: 25-48.

Sarı D. 2017. Frigya Daglık Bölgesi'nde Yer Alan Keçiçayırı Ilk Tunç Çagı II Kalesi Küçük Buluntuları. Arkeoloji Dergisi 22: 117-147.

Seeher J. 1987. Demircihüyük, Band III,1, Die Keramik 1, A. Die Neolithische und Chalkolithische Keramik, B. Die Frühbronzezeitliche Keramik Der Älteren Phasen (bis Phase G). Verlag Philipp von Zabern. Mainz Am Rhein.

Weninger B., Clare L., Gerritsen F., Horejs B., Krauß R., Linstädter J., Özbal R., and Rohling E. J. 2014. Neolithisation of the Aegean and Southeast Europe During the 66006000 calBC Period of Rapid Climate Change. Documenta Praehistorica 41: 1-31. https://doi.org/10.4312/dp.41.1 




1


10
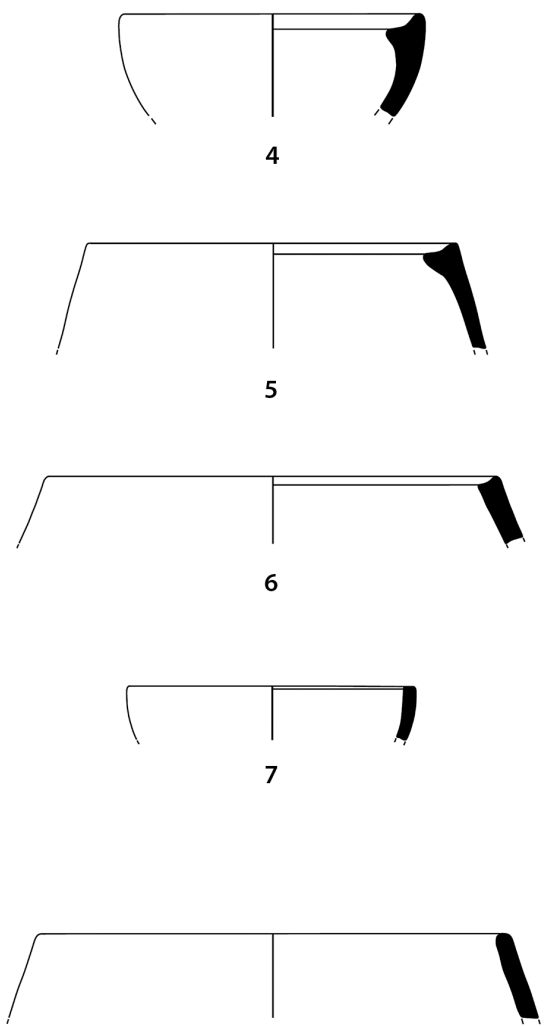

11

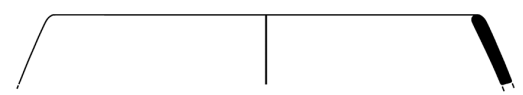

12

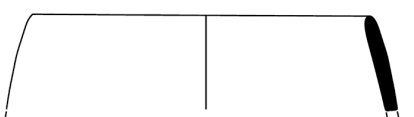

13

Pl. 1. 1. AY-1. 247. Simple profile bowl. Dark faced ware. Black biscuit with straw and stone inclusions. Light brown surface burnished, mottled black; 2. AY-1. 250. Simple profile bowl. Dark faced ware. Micaceous black biscuit with some small stone and straw inclusions. Light brown surface burnished; 3. AY-1. 250. Simple profile bowl. Red Slipped Ware. Micaceous light brown biscuit with small stone and chalk inclusions. Red slipped surface burnished; 4. AY-1. 198. Ledge-rim bowl. Dark Faced Ware. Micaceous light brown biscuit with small stone inchusions. Dark brown surface burnished; 5. AY-1. 260. Ledgerim bowl. Dark Faced Ware. Micaceous black biscuit with some coarse stone inclusions. Light brown surface burnished; 6. AY/AZ-1. 280. Ledge-rim bowl. Coarse Ware. Micaceous dark brow biscuit with coarse stone and chalk inclusions. Light brown surface unburnished; 7. AY/AZ-1. 267. Ledge-rim bowl. Dark Faced Ware. Light brown surface unburnished. Brown biscuit with small stone and chalk inclusions; 8. AY/AZ-1. 291. 'S'-profile bowls. Dark Faced Ware. Light brown biscuit with straw and chalk inclusions. Reddish brown surface burnished, black mottled on the rim; 9. AY-1. 226. 'S'-profile bowls. Red Slipped Ware. Micaceous biscuit with small stone inclusions. Red slipped surface on exterior and interior; 10. AY/AZ-1. 267. 'S'-profile bowls. Dark Faced Ware. Micaceous dark brown biscuit with small stone and chalk inclusions. Black surface fine burnished; 11. AY-1. 244. Hole-mouthed jar. Dark Faced Ware. Micaceous dark brown biscuit with small stone and straw inclusions. Brown surfaces burnished; 12 . AY/AZ-1. 267. Hole-mouthed jar. Coarse Ware. Dense micaceous light brown biscuit with stone inclusions. Buff surface unburnished; 13. AY/AZ-1. 278. Hole-mouthed jar. Dark Faced Ware. Micaceous brown biscuit with small stone inclusions. Light brown surface burnished. 


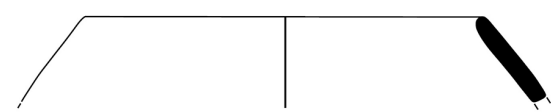

14

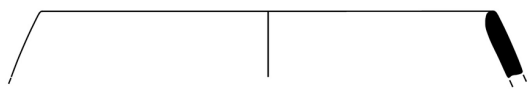

15

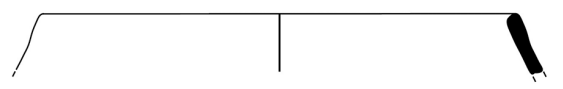

16



17



22



23

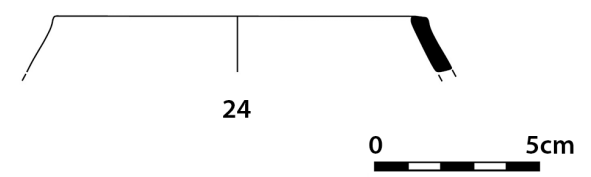

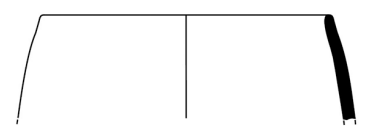

18

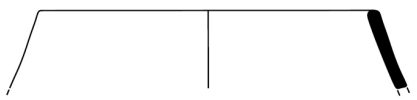

19

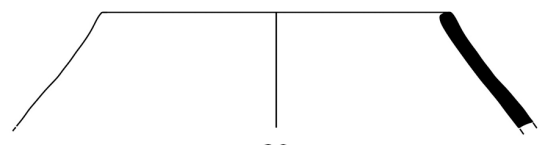

20

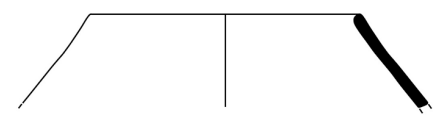

21



25



26

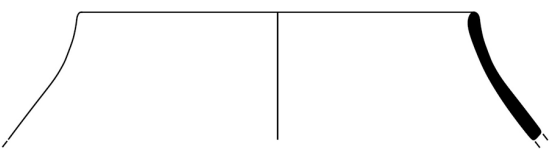

27

Pl. 2. 14. AY-1. 247. Hole-mouthed jar. Dark Faced Ware. Black biscuit with small stone and scarcely straw inclusions. Brown surfaces burnished, mottled; 15. AY-1. 282. Hole-mouthed jar. Dark Faced Ware. Micaceous black biscuit with small stone inclusions. Greyish brown surface wet-smoothed; 16. AY-1. 247. Holemouthed jar. Dark Faced Ware. Brown biscuit with coarse stone inclusions. Brown surface wet-smoothed; 17. AY/AZ-1. 272. Hole-mouthed jar. Dark Faced Ware. Micaceous brown biscuit with coarse stone inclusions. Brown surfaces burnished, brilliant on exterior; 18. AY-1. 247. Hole-mouthed jar. Red Slipped Ware. Red slipped on both surfaces. Micaceous black biscuit with small stone and chalk inclusions; 19. AY-1. 244. Hole-mouthed jar. Red Slipped Ware. Micaceous black biscuit with small stone inclusions. Maroon slipped surface burnished; 20. AY-1. 247. Hole-mouthed jar. Red Slipped Ware. Micaceous black biscuit with small stone inclusions. Maroon slipped surface burnished; 21. AY-1. 260. Dark Faced Ware. Greyish brown surface smoothed on exterior. Micaceous black biscuit with small stone inclusions; 22. AY/AZ-1. 241. Squat-necked jar. Dark Faced Ware. Micaceous black biscuit with small stone and chalk inclusions. Dark brown surface burnished; 23. AY/AZ-1. 241. Squat-necked jar. Red Slipped Ware. Red slipped surface, mottled on rim. Black biscuit with small stone and chalk inclusions; 24. AY-1. 282. Squatnecked jar. Dark Faced Ware Greyish brown surface smoothed on exterior. Micaceous dark brown biscuit with coarse stone inclusions; 25. AY/AZ-1. 272. Necked jar. Dark Faced Ware. Micaceous blackish brown biscuit with small stone inclusions. Dark brown surface fine burnished; 26. AY-1. 226. Necked jar. Red Slipped Ware. Red slipped surface burnished. Micaceous light brown biscuit with stone inclusions; 27. AY-1. 226. Necked jar. Dark Faced Ware. Brown biscuit with small stone inclusions. Light brown surface burnished. 


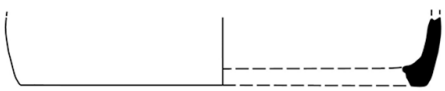

28
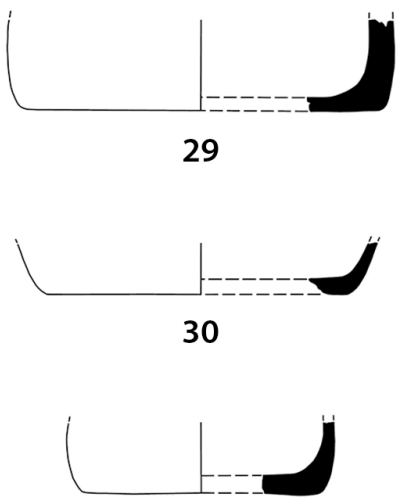

31

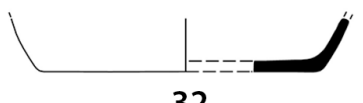

32



33

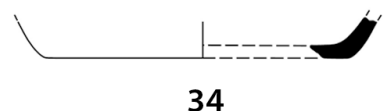

34

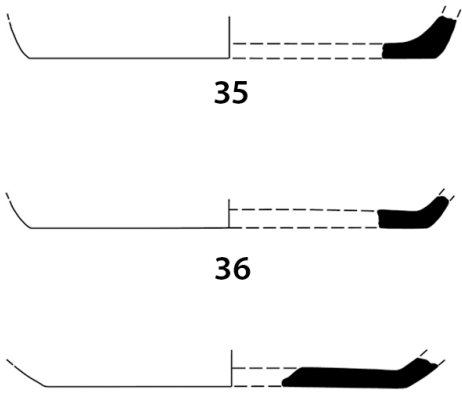

37

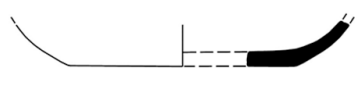

38
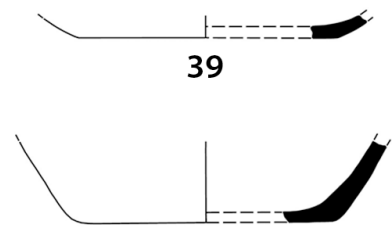

40

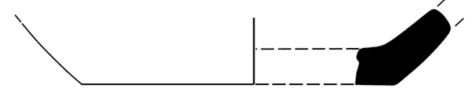

41

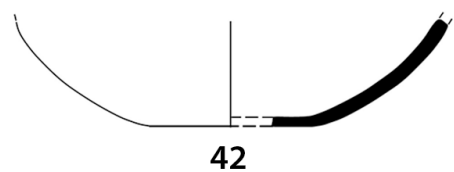

42



43

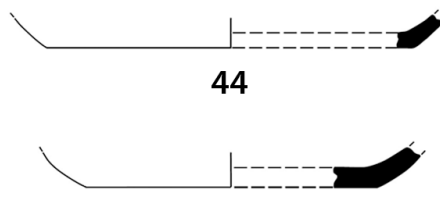

45



0 $5 \mathrm{~cm}$

Pl. 3. 28. AY-1. 247. Base. Dark Faced Ware. Micaceous black biscuit with stone inclusions. Greyish brown surface wet-smoothed; 29. AY-1. 260. Base. Dark Faced Ware. Brown surface burnished on lower body. Black biscuit with stone inclusions; 30. AY/AZ-1. 278. Base. Dark Faced Ware. Light brown biscuit with stone inclusions. Light brown surface burnished on lower body; 31. AY-1. 247. Base. Dark Faced Ware. Dark brown biscuit with stone inclusions. Light brown surface burnished on lower body; 32. AV-1/2. 32. Base. Dark Faced Ware. Micaceous light brown biscuit with small stone inclusions. Light brown surface burnished on lower body; 33. AV-1/2. 32. Base. Dark Faced Ware. Dark brown biscuit with stone inclusions. Light brown surface burnished on lower body; 34. AY-1. 247. Base. Dark Faced Ware. Micaceous black biscuit with stone inclusions. Dark brown surface burnished on lower body; 35. AY/AZ-1. 291. Base. Coarse Ware. Micaceous brown biscuit with coarse stone inclusions. Light brown surface unburnished on lower body; 36. AY/AZ-1. 267. Base. Dark Faced Ware. Brown biscuit with coarse stone inclusions. Brown chalky surface; 37. AY/AZ-1. 278. Base. Dark Faced Ware. Micaceous black biscuit with stone inclusions. Brown surface burnished on lower body; 38. AY/AZ-1. 278. Base. Dark Faced Ware. Micaceous dark brown biscuit with stone inclusions. Brown surface fine burnished on lower body; 39. AY/AZ-1. 241. Base. Red Slipped Ware. Light brown biscuit with small stone inclusions. Red slipped surface burnished; 40. AY/AZ-1. 280. Base. Coarse Ware. Dark brown biscuit with coarse stone inclusions and slightly micaceous. Dark brown surface unburnished; 41. AY/AZ-1. 241. Base. Dark Faced Ware. Brown biscuit with stone inclusions and slightly micaceous. Brown surface unburnished; 42. AY-1. 228. Base. Red Slipped Ware. Light brown biscuit with small stone inclusions and slightly micaceous. Red slipped surface burnished; 43. AY/AZ-1. 267. Base. Coarse Ware. Brown biscuit with stone inclusions and slightly micaceous. Light brown surface unburnished; 44. AY-1. 250. Base. Dark Faced Ware. Micaceous brown biscuit with stone inclusions. Dark brown surface unburnished; 45. AY/AZ-1. 241. Base. Dark Faced Ware. Micaceous brown biscuit with stone inclusions. Light brown surface smoothed; 46. AY-1. 247. Base. Dark Faced Ware. Black biscuit with small stone inclusions and slightly micaceous. Blackish brown surface burnished. 


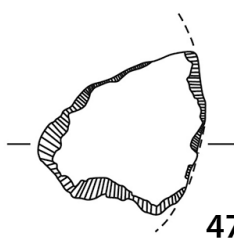

47

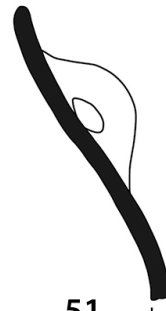

51

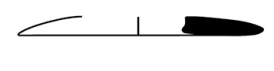

48

0

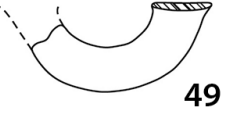

49

$5 \mathrm{~cm}$



52

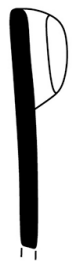

53

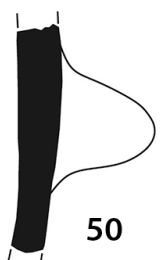

50

Pl. 4. 47. AV-1/2. 40. Lid. Dark Faced Ware. Micaceous dark brown biscuit with stone inclusions. Brown surface smoothed; 48. AY-1. 228. Lid. Dark Faced Ware. Micaceous brown biscuit with stone inclusions. Light brown surface smoothed; 49. AY/AZ-1. 278. Horizontal handle. Dark Faced Ware. Micaceous light brown biscuit with stone inclusions. Light brown surface smoothed; 50. AY-1. 259. Horizontal lug. Dark Faced Ware. Brown biscuit slightly micaceous with stone inclusions. Light brown surface burnished, black mottled below the lug; 51. AY/AZ-1. 278. Vertical handle. Dark Faced Ware. Micaceous dark brown biscuit with small stone inclusions. Light brown surface burnished; 52. AY/AZ-1. 278. Pierced lug. Dark Faced Ware. Micaceous dark brown biscuit with small stone inclusions. Greyish brown surface burnished; 53. AY-1. 275. Pierced lug. Dark Faced Ware. Micaceous brown biscuit with small stone inclusions. Light brown surface burnished; 54. AY-1. 259. Pierced lug. Dark Faced Ware. Micaceous brown biscuit with coarse stone inclusions with a black core. Dark brown surface burnished.

back to contents 